\title{
ASPOROGENOUS YEASTS AND THEIR SUPPOSED ASCOSPOROGENOUS STATES: AN ELECTROPHORETIC COMPARISON OF ENZYMES
}

\author{
MASASHI YAMAZAKI ${ }^{1}$ AND KAZUO KOMAGATA \\ The Institute of Applied Microbiology, University of Tokyo, \\ Bunkyo-ku, Tokyo 113, Japan
}

(Received October 27, 1981)

\begin{abstract}
The relationship of nine Candida species, five Torulopsis species, and five species and two varieties of Kloeckera to the ascosporogenous yeast species considered to be their teleomorphs was studied by electrophoretic comparison of enzymes. Close relationships were seen between fourteen teleomorphs and their anamorphic counterparts, Candida guilliermondii and Pichia guilliermondii, Candida krusei and Issatchenkia orientalis (Pichia kudriavzevii), Candida lambica and Pichia fermentans, Candida melinii and Hansenula wingei, Candida utilis and Hansenula jadinii, Candida macedoniensis and Kluyveromyces marxianus, Candida pseudotropicalis and Kluyveromyces fragilis, Candida parapsilosis (group 2) and Lodderomyces elongisporus, Torulopsis holmii and Saccharomyces exiguus, Torulopsis colliculosa and Torulaspora delbrueckii (Saccharomyces fermentati), Torulopsis stellata and Torulaspora delbrueckii (Saccharomyces rosei), Kloeckera africana and Hanseniaspora vinea, Kloeckera apiculata and Hanseniaspora uvarum, and Kloeckera japonica and Hanseniaspora valbyensis. There was no apparent relation between the four pairs: Candida valida and Pichia membranaefaciens, Candida parapsilosis (group 1) and Lodderomyces elongisporus, Torulopsis molischiana and Hansenula capsulata, and Torulopsis candida and Debaryomyces hansenii and Debaryomyces marama. From these results, this zymographic technique is considered to be a useful tool for the study of relalationships between the different states of a yeast species.
\end{abstract}

In a previous paper (1), the present authors reported that an electrophoretic comparison of enzymes was a useful tool to clarify the taxonomical and physiological relationships among the strains of the genera Rhodotorula and Rhodosporidium.

1 Present address: Research Institute of Fermentation, Yamanashi University, Kofu 400, Japan. 
A number of Torulopsis and Candida species are considered to be anamorphs of ascosporogenous yeast species (2-18).

The present paper deals with the electrophoretic comparison of enzymes of some species of Candida, Torulopsis, and Kloeckera with their supposed teleomorphic states, and discusses the relationship between them.

YARROW and MEYER (19) proposed transferring the species classified in Torulopsis to the genus Candida, but we found it convenient to use the generic name of Torulopsis in this paper.

\section{MATERIALS AND METHODS}

Microorganisms. Thirteen strains of nine Candida species, thirteen strains of five Torulopsis species, seven strains of five Kloeckera species and two varieties, three strains of three Pichia species, one strain of Issatchenkia orientalis, two strains of two Kluyveromyces species, one strain of Lodderomyces elongisporus, three strains of three Hansenula species, three strains of Torulaspora delbrueckii, one strain of Saccharomyces exiguus, two strains of two Debaryomyces species, and four strains of three Hanseniasopra species were employed. Sources of cultures are shown in Tables 1-3.

Cultivation and harvesting of cells, preparation of cell-free extracts, and gelslab electrophoresis. Methods for cultivation and harvesting of cells, preparation of cell-free extracts, and gel-slab electrophoresis were essentially the same as those reported previously (1).

Staining procedures. Fructose-1,6-bisphosphate aldolase (FA; EC 4.1.2.13.), 6-phosphogluconate dehydrogenase (6PGDH; EC 1.1.1.41), malate dehydrogenase (MDH; EC 1.1.1.37), hexokinase (HK; EC 2.7.1.1), phosphoglucomutase (PGm; EC 2.7.5.1), glucose-6-phosphate dehydrogenase (G6PDH; EC 1.1.1.49), glutamate dehydrogenase $(\mathrm{GDH} ; \mathrm{EC}$ 1.4.1.4), lactate dehydrogenase (LDH; EC 1.1.1.27), fumarase (EC; 4.2.1.2), and non-specific esterase (EC 3.1.1.1) were investigated. The staining procedures of the enzymes examined were those described by Siciliano and SHaw (20). The relative mobilities (Rm) of the enzymes were calculated as the ratio of the distance that the enzyme moved from the origin to the distance that the tracking dye moved.

\section{RESULTS}

Figure 1 shows the electrophoretic patterns of seven enzymes of some pairs of asporogenous yeasts and their supposed ascosporogenous states.

Electrophoretic comparison of enzymes between nine Candida species and their supposed ascosporogenous states

The relative electrophoretic mobilities ( $\mathrm{Rm}$ ) of enzymes of nine Candida species and those of their supposed ascosporogenous states are shown in Table 1. 


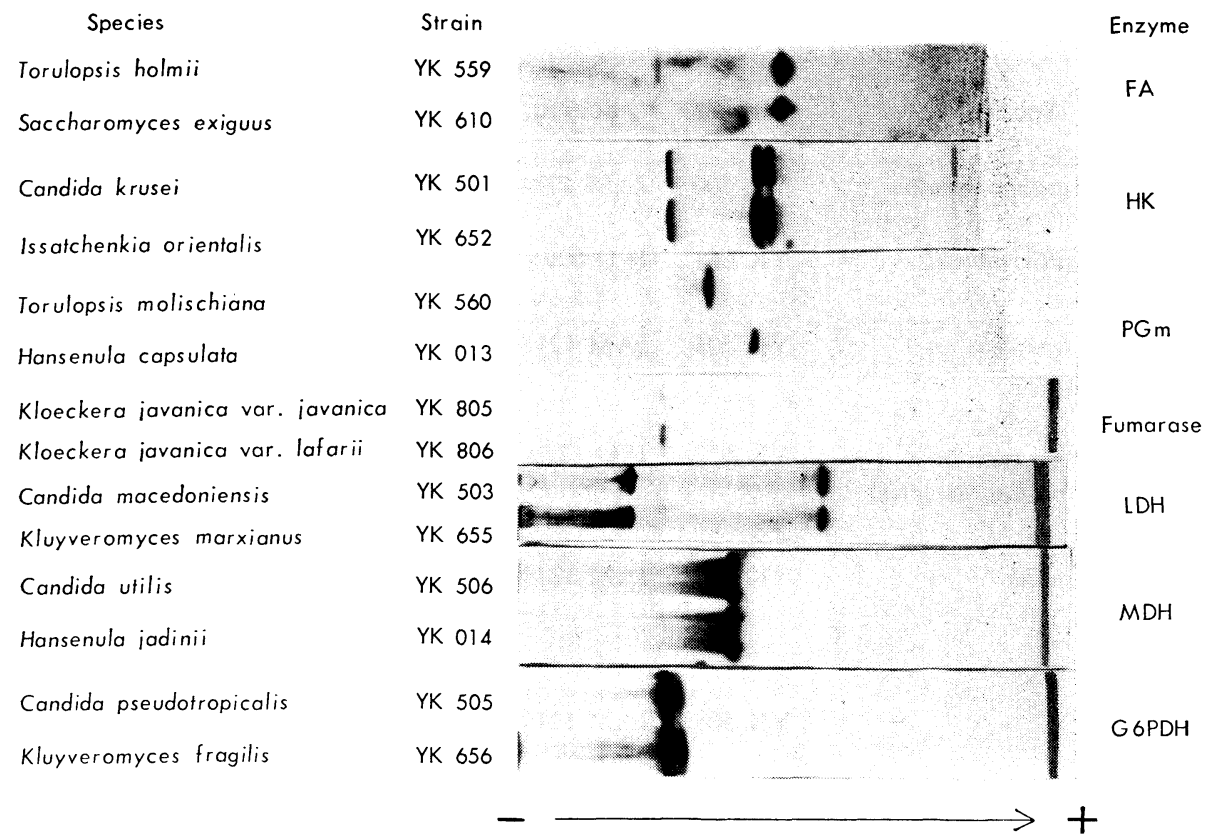

Fig. 1. Polyacrylamide gel stained for FA, HK, PGm, fumarase, LDH, MDH, and G6PDH in some pairs of anamorph and teleomorph counterparts.

The patterns for all ten enzymes of the strains of Candida guilliermondii $\mathrm{YK}$ 500 and Pichia guilliermondii YK 651, Candida krusei YK 501 and Issatchenkia orientalis (Pichia kudriavzevii) YK 652, Candida lambica YK 502 and Pichia fermentans YK 653, Candida macedoniensis YK 503 and Kluyveromyces marxianus YK 655, and Candida pseudotropicalis YK 505 and Kluyveromyces fragilis YK 656 were the same.

Candida melinii YK 504 and Hansenula wingei YK 038 exhibited identical patterns except for esterase.

Candida utilis YK 506 was similar to Hansenula jadinii YK 014 for the respective enzymes except FA.

Of two Candida valida strains tested, the strain YK 508 was similar to Pichia membranaefaciens YK 654 with respect to $6 \mathrm{PGDH}, \mathrm{MDH}$, and $\mathrm{LDH}$ patterns but not for the other enzymes. The other strain, YK 507, produced similar patterns to $P$. membranaefaciens YK 654 for MDH, PGm, and G6PDH but not for the other enzymes.

Four Candida parapsilosis strains tested split into two groups on the basis of their enzymatic patterns. The first group comprised the two strains YK 509 and YK 510, and the second group the two strains YK 511 and YK 512. Lodderomyces elongisporus YK 690 produced the same enzymatic patterns as the second group. 
Table 1. Electrophoretic comparison of enzymes between nine

\begin{tabular}{|c|c|c|c|c|c|c|}
\hline Species & Strain & Source & FA & $6 \mathrm{PGDH}$ & MDH & $\mathrm{LDH}$ \\
\hline Candida guilliermondii & YK 500 & IAM 4974 & 0.54 & 0.38 & 0.40 & 0.57 \\
\hline Pichia guilliermondii & YK 651 & IFO 0961 & 0.54 & 0.38 & 0.40 & 0.57 \\
\hline Candida krusei & YK 501 & IAM 12186 & 0.52 & $\begin{array}{l}0.20 \\
0.45\end{array}$ & 0.34 & $\begin{array}{l}0.21 \\
0.60\end{array}$ \\
\hline $\begin{array}{l}\text { Issatchenkia orientalis } \\
\quad \text { (Pichia kudriavzevii) }\end{array}$ & YK 652 & IFO 1279 & 0.52 & $\begin{array}{l}0.20 \\
0.45\end{array}$ & 0.34 & $\begin{array}{l}0.21 \\
0.60\end{array}$ \\
\hline Candida valida & YK 507 & IAM 12190 & 0.52 & $\begin{array}{l}0.20 \\
0.45\end{array}$ & 0.35 & $\begin{array}{l}0.21 \\
0.60\end{array}$ \\
\hline & YK 508 & IAM 12191 & 0.39 & 0.36 & 0.34 & $\begin{array}{l}0.18 \\
0.53\end{array}$ \\
\hline Pichia membranaefaciens & YK 654 & IAM 4987 & 0.44 & 0.35 & 0.34 & $\begin{array}{l}0.14 \\
0.53\end{array}$ \\
\hline Candida lambica & YK 502 & AJ 4461 & 0.51 & 0.46 & 0.36 & $\begin{array}{l}0.19 \\
0.62\end{array}$ \\
\hline Pichia fermentans & YK 653 & IFO 1164 & 0.51 & 0.46 & 0.36 & $\begin{array}{l}0.19 \\
0.62\end{array}$ \\
\hline Candida macedoniensis & YK 503 & IFO 0706 & 0.45 & 0.48 & 0.43 & $\begin{array}{l}0.21 \\
0.59\end{array}$ \\
\hline Kluyveromyces marxianus & YK 655 & IFO 0690 & 0.45 & 0.48 & 0.43 & $\begin{array}{l}0.21 \\
0.59\end{array}$ \\
\hline Candida pseudotropicalis & YK 505 & IAM 4829 & 0.45 & - & 0.43 & $\begin{array}{l}0.19 \\
0.55 \\
0.57\end{array}$ \\
\hline Kluyveromyces fragilis & YK 656 & IAM 12237 & 0.45 & - & 0.43 & $\begin{array}{l}0.19 \\
0.53 \\
0.55 \\
0.57\end{array}$ \\
\hline Candida melinii & YK 504 & IFO 0747 & 0.49 & 0.30 & $\begin{array}{l}0.39 \\
0.49\end{array}$ & $\begin{array}{l}0.22 \\
0.55\end{array}$ \\
\hline Hansenula wingei & YK 038 & NRRLY-2340 & 0.49 & 0.30 & $\begin{array}{l}0.39 \\
0.49\end{array}$ & $\begin{array}{l}0.22 \\
0.55\end{array}$ \\
\hline
\end{tabular}


Candida species and their supposed ascosporogenous states.

\begin{tabular}{|c|c|c|c|c|c|c|c|}
\hline HK & PGm & G6PDH & Fumarase & GDH & Esterase & $\begin{array}{c}\mathrm{G}+\mathrm{C} \text { contents } \\
\text { of DNAs } \\
(\mathrm{mol} \%)^{a}\end{array}$ & Co $\mathrm{Q}^{b}$ \\
\hline $\begin{array}{l}0.51 \\
0.68\end{array}$ & 0.50 & 0.28 & 0.24 & 0.13 & $0.54,0.56$ & 44.1 & 9 \\
\hline $\begin{array}{l}0.51 \\
0.68\end{array}$ & 0.50 & 0.28 & 0.24 & 0.13 & $0.54,0.56$ & 44.6 & 9 \\
\hline $\begin{array}{l}0.39 \\
0.58 \\
0.60\end{array}$ & 0.40 & $\begin{array}{l}0.40 \\
0.42\end{array}$ & 0.27 & 0.17 & $\begin{array}{l}0.61,0.63 \\
0.65,0.68 \\
0.75\end{array}$ & 39.3 & 7 \\
\hline $\begin{array}{l}0.39 \\
0.58 \\
0.60\end{array}$ & 0.40 & $\begin{array}{l}0.38 \\
0.40\end{array}$ & 0.27 & 0.17 & $\begin{array}{l}0.61,0.63 \\
0.68,0.84\end{array}$ & 38.5 & 7 \\
\hline $\begin{array}{l}0.39 \\
0.55 \\
0.60 \\
0.63 \\
0.67\end{array}$ & 0.55 & 0.38 & 0.27 & 0.17 & $\begin{array}{l}0.79,0.81 \\
0.84\end{array}$ & 38.5 & 7 \\
\hline $\begin{array}{l}0.28 \\
0.63\end{array}$ & 0.40 & 0.38 & 0.30 & 0.11 & 0.67 & 42.0 & 7 \\
\hline $\begin{array}{l}0.58 \\
0.65 \\
0.58 \\
0.61\end{array}$ & $\begin{array}{l}0.53 \\
0.55 \\
0.55\end{array}$ & $\begin{array}{l}0.44 \\
0.46 \\
0.40 \\
0.42 \\
0.44\end{array}$ & $\begin{array}{l}0.35 \\
0.35\end{array}$ & $\begin{array}{l}0.15 \\
0.15\end{array}$ & $\begin{array}{l}0.56,0.64 \\
0.75,0.78 \\
0.56,0.64 \\
0.75\end{array}$ & $\begin{array}{l}42.9 \\
42.2\end{array}$ & 7 \\
\hline $\begin{array}{l}0.47 \\
0.65 \\
0.47 \\
0.65\end{array}$ & $\begin{array}{l}0.42 \\
0.50 \\
0.50\end{array}$ & $\begin{array}{l}0.28 \\
0.31 \\
0.28 \\
0.31\end{array}$ & $\begin{array}{l}0.34 \\
0.34\end{array}$ & $\begin{array}{l}0.17 \\
0.17\end{array}$ & $\begin{array}{l}0.44,0.48 \\
0.41,0.48\end{array}$ & $\begin{array}{l}39.8 \\
41.0\end{array}$ & 6 \\
\hline $\begin{array}{l}0.45 \\
0.47 \\
0.63 \\
0.65 \\
0.45 \\
0.47 \\
0.63 \\
0.65\end{array}$ & 0.47 & $\begin{array}{l}0.28 \\
0.31\end{array}$ & $\begin{array}{l}0.30 \\
0.34\end{array}$ & 0.17 & 0.48 & 40.0 & 6 \\
\hline $\begin{array}{l}0.47 \\
0.52\end{array}$ & 0.52 & $\begin{array}{l}0.28 \\
0.30 \\
0.32\end{array}$ & 0.24 & 0.14 & $0.54,0.61$ & 39.5 & 7 \\
\hline $\begin{array}{l}0.47 \\
0.52 \\
0.56\end{array}$ & $\begin{array}{l}0.52 \\
0.56\end{array}$ & $\begin{array}{l}0.28 \\
0.30 \\
0.32\end{array}$ & 0.24 & 0.14 & $0.59,0.65$ & 39.0 & 7 \\
\hline
\end{tabular}


Table 1.

\begin{tabular}{|c|c|c|c|c|c|c|}
\hline Species & Strain & Source & FA & 6PGDH & $\mathrm{MDH}$ & LDH \\
\hline Candida utilis & YK 506 & IAM 4961 & 0.53 & 0.26 & 0.41 & $\begin{array}{l}0.26 \\
0.51\end{array}$ \\
\hline Hansenula jadinii & YK 014 & NRRLY-1542 & 0.49 & 0.26 & 0.41 & $\begin{array}{l}0.26 \\
0.51\end{array}$ \\
\hline \multirow[t]{4}{*}{ Candida parapsilosis } & YK 509 & IAM 12192 & 0.58 & 0.33 & $\begin{array}{l}0.28 \\
0.42\end{array}$ & 0.58 \\
\hline & YK 510 & IAM 12270 & 0.58 & 0.33 & $\begin{array}{l}0.28 \\
0.42\end{array}$ & 0.58 \\
\hline & YK 511 & $\mathrm{AJ} 4575$ & 0.55 & 0.36 & $\begin{array}{l}0.32 \\
0.36\end{array}$ & $\begin{array}{l}0.14 \\
0.61\end{array}$ \\
\hline & YK 512 & AJ 4571 & 0.55 & 0.36 & $\begin{array}{l}0.32 \\
0.36\end{array}$ & $\begin{array}{l}0.14 \\
0.61\end{array}$ \\
\hline Lodderomyces elongisporus & YK 690 & AJ 5470 & 0.55 & - & $\begin{array}{l}0.36 \\
0.38 \\
0.40\end{array}$ & $\begin{array}{l}0.14 \\
0.61\end{array}$ \\
\hline
\end{tabular}

a Nakase and Komagata $(3,5,7,21)$

$b$ YAMADA et al. $(11,40,41)$

Abbreviations: IAM, Institute of Applied Microbiology, University of Tokyo, Ajinomoto Co., Inc., Kawasaki, Japan; NRRL, ARS Culture Collection, Northern

Electrophoretic comparison of enzymes between five Torulopsis species and their supposed ascosporogenous states

The relative electrophoretic mobilities ( $\mathrm{Rm}$ ) of the enzymes of five Torulopsis species and those of their supposed ascosporogenous states are shown in Table 2.

Torulopsis holmii YK 559 produced the same enzymatic patterns as Saccharomyces exiguus YK 610.

The patterns of Torulopsis colliculosa YK 561 and two strains YK 611 and YK 659 of Torulaspora delbrueckii were identical.

The patterns of Torulopsis molischiana YK 560 differed from those of Hansenula capsulata YK 013.

Of two Torulopsis stellata strains tested, the strain YK 563 was similar to Torulaspora delbrueckii YK 612 with respect to LDH, HK, fumarase, GDH, and G6PDH patterns but not to FA, PGm, and esterase patterns. The other strain YK 562 produced similar enzymatic patterns to $T$. delbrueckii YK 612 for FA and fumarase but not for MDH, LDH, HK, PGm, G6PDH, and GDH.

The eight Torulopsis candida strains fell into three groups on the basis of their enzymatic patterns. The first group consisted of five strains: YK 551, YK 552, YK 553, YK 554, and YK 555. These strains produced identical en- 
Continued

\begin{tabular}{|c|c|c|c|c|c|c|c|}
\hline $\mathrm{HK}$ & PGm & G6PDH & Fumarase & $\mathrm{GDH}$ & Esterase & $\begin{array}{c}\mathrm{G}+\mathrm{C} \text { contents } \\
\text { of DNAs } \\
(\mathrm{mol} \%)^{a}\end{array}$ & Co $\mathrm{Q}^{b}$ \\
\hline 0.55 & 0.68 & 0.40 & 0.29 & 0.13 & 0.82 & 44.0 & 7 \\
\hline 0.61 & & 0.42 & & & & & \\
\hline 0.55 & 0.68 & 0.40 & 0.29 & 0.13 & 0.82 & 43.2 & 7 \\
\hline 0.58 & & 0.42 & & & & & \\
\hline \multicolumn{8}{|l|}{0.61} \\
\hline 0.56 & 0.56 & 0.28 & 0.22 & 0.06 & 0.58 & 40.0 & \\
\hline 0.61 & & 0.31 & 0.29 & 0.12 & & & \\
\hline 0.56 & 0.56 & 0.28 & 0.22 & 0.06 & 0.58 & & 9 \\
\hline 0.61 & & 0.31 & 0.29 & 0.12 & & & \\
\hline 0.45 & 0.59 & 0.31 & 0.24 & 0.13 & 0.62 & 39.3 & \\
\hline 0.61 & & 0.34 & 0.27 & & & & \\
\hline \multicolumn{8}{|l|}{0.66} \\
\hline 0.45 & 0.59 & 0.31 & 0.24 & 0.13 & 0.62 & 39.3 & \\
\hline 0.61 & & 0.34 & 0.27 & & & & \\
\hline \multicolumn{8}{|l|}{0.66} \\
\hline 0.45 & 0.59 & 0.31 & 0.24 & 0.13 & 0.62 & & 9 \\
\hline 0.61 & & 0.32 & 0.27 & & & & \\
\hline 0.66 & & 0.34 & & & & & \\
\hline
\end{tabular}

Japan; IFO, Institute for Fermentation, Osaka, Japan; AJ, Central Research Laboratories, Regional Research Center, U.S. Department of Agriculture, Peoria, U.S.A.

zymatic patterns for FA, 6PGDH, LDH, PGm, G6PDH, fumarase, and GDH and showed a slight variation with respect to $\mathrm{MDH}(\mathrm{Rm} 0.54-0.58)$, HK (Rm $0.41-0.45)$, and esterase ( $\mathrm{Rm} 0.53-0.56)$. The second group consisted of two strains, YK 556 and YK 557, which produced identical patterns for all ten enzymes. This group did not show the same enzymatic patterns as did the first group except for G6PDH and GDH. The third group comprised one strain, YK 558, which was similar to the first group with respect to fumarase and the second group with respect to LDH and esterase but not to the other enzymes. The first group was similar to Debaryomyces hansenii $\mathrm{YK} 657$ with respect to 6PGDH, PGm, and G6PDH, and to Debaryomyces marama YK 658 with respect to $\mathrm{MDH}(\mathrm{Rm} 0.58)$ and HK (Rm 0.45), but not to either Debaryomyces species for the other enzymes. The second group produced the same enzymatic patterns as D. hansenii YK 657 for G6PDH and D. marama YK 658 for 6PGDH but not for the other enzymes. The third group was not similar to D. hansenii YK 657 and D. marama YK 658 for any of the enzymes.

Electrophoretic comparison of enzymes between the genera Kloeckera and Hanseniaspora

The relative electrophoretic mobilities $(\mathrm{Rm})$ of enzymes of the genera 
Table 2. Electrophoretic comparison of enzymes between five

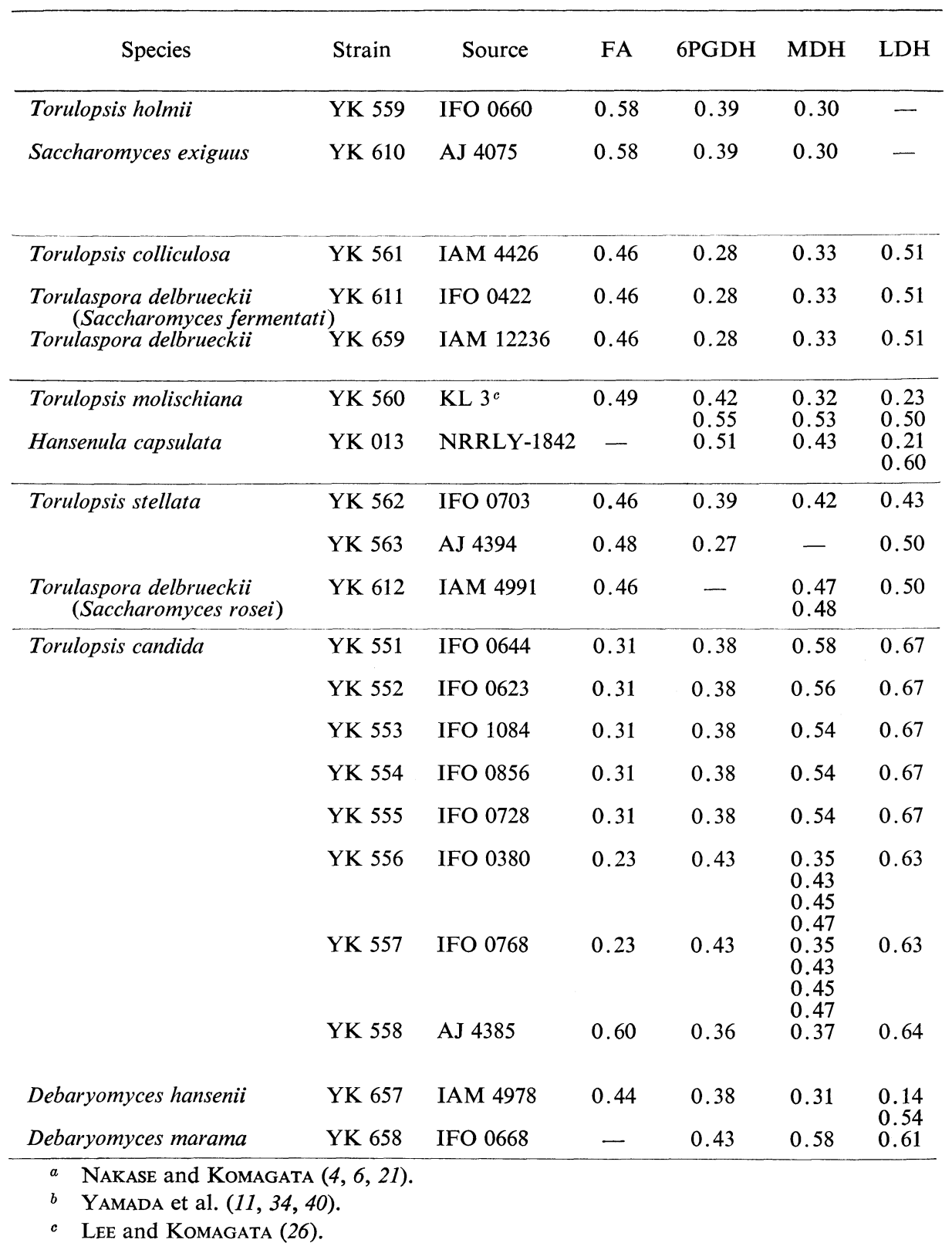


Torulopsis species and their supposed ascosporogenous states.

\begin{tabular}{|c|c|c|c|c|c|c|c|}
\hline HK & PGm & G6PDH & Fumarase & GDH & Esterase & $\begin{array}{c}\mathrm{G}+\mathrm{C} \text { contents } \\
\text { of DNAs } \\
(\mathrm{mol} \%)^{a}\end{array}$ & Co $\mathrm{Q}^{b}$ \\
\hline $\begin{array}{l}0.34 \\
0.52\end{array}$ & 0.32 & $\begin{array}{l}0.35 \\
0.37\end{array}$ & 0.27 & 0.19 & $\begin{array}{l}0.51,0.58 \\
0.66\end{array}$ & 34.1 & 6 \\
\hline $\begin{array}{l}0.34 \\
0.37 \\
0.45 \\
0.52\end{array}$ & 0.32 & $\begin{array}{l}0.33 \\
0.35 \\
0.37\end{array}$ & 0.27 & 0.19 & $\begin{array}{l}0.51,0.58 \\
0.66\end{array}$ & 33.7 & 6 \\
\hline 0.35 & 0.25 & $\begin{array}{l}0.38 \\
0.40\end{array}$ & 0.24 & 0.14 & - & 42.2 & 6 \\
\hline 0.35 & 0.36 & $\begin{array}{l}0.36 \\
0.38\end{array}$ & 0.24 & 0.14 & - & 43.2 & 6 \\
\hline 0.35 & 0.36 & $\begin{array}{l}0.36 \\
0.38 \\
\end{array}$ & 0.24 & 0.14 & & 42.9 & 6 \\
\hline $\begin{array}{l}0.42 \\
0.69\end{array}$ & 0.43 & 0.46 & 0.36 & 0.15 & 0.72 & $47.2^{c}$ & $8^{c}$ \\
\hline $\begin{array}{l}0.39 \\
0.56 \\
\end{array}$ & 0.59 & - & 0.36 & 0.19 & $0.42,0.65$ & $47.1^{c}$ & $8^{c}$ \\
\hline $\begin{array}{l}0.66 \\
0.67\end{array}$ & 0.48 & 0.24 & 0.24 & 0.08 & 0.58 & & 8 \\
\hline 0.35 & 0.38 & $\begin{array}{l}0.36 \\
0.38\end{array}$ & 0.24 & 0.14 & 0.41 & 42.9 & 6 \\
\hline 0.35 & 0.26 & $\begin{array}{l}0.38 \\
0.41 \\
\end{array}$ & 0.24 & 0.14 & 0.33 & 42.9 & 6 \\
\hline 0.44 & - & - & $\begin{array}{l}0.35 \\
0.38\end{array}$ & 0.16 & 0.56 & & \\
\hline 0.43 & 0.43 & 0.38 & $\begin{array}{l}0.35 \\
0.38\end{array}$ & 0.16 & 0.53 & 36.8 & 9 \\
\hline 0.45 & 0.43 & 0.38 & & 0.16 & $0.53,0.78$ & & \\
\hline 0.43 & 0.43 & 0.38 & $\begin{array}{l}0.35 \\
0.38\end{array}$ & 0.16 & $0.53,0.78$ & & \\
\hline 0.41 & 0.43 & 0.38 & & 0.16 & 0.54 & & \\
\hline $\begin{array}{l}0.40 \\
0.59\end{array}$ & 0.58 & 0.38 & $\begin{array}{l}0.34 \\
0.35\end{array}$ & 0.16 & $0.65,0.69$ & & \\
\hline $\begin{array}{l}0.40 \\
0.59\end{array}$ & 0.60 & 0.38 & $\begin{array}{l}0.34 \\
0.35\end{array}$ & 0.16 & $0.65,0.69$ & & \\
\hline 0.55 & 0.56 & $\begin{array}{l}0.32 \\
0.34\end{array}$ & $\begin{array}{l}0.35 \\
0.36 \\
0.38\end{array}$ & 0.21 & 0.65 & 42.9 & \\
\hline 0.28 & 0.43 & $\begin{array}{l}0.36 \\
0.38\end{array}$ & 0.30 & 0.12 & 0.51 & 34.5 & 9 \\
\hline 0.45 & 一 & 0.36 & 0.31 & 0.12 & 0.60 & 36.6 & 9 \\
\hline
\end{tabular}


Table 3. Grouping of the genera Kloeckera and

\begin{tabular}{|c|c|c|c|c|c|c|}
\hline Group & Species & Strain & Source & FA & 6PGDH & $\mathrm{MDH}$ \\
\hline \multirow[t]{2}{*}{1} & $K$. africana & YK 803 & IAM 4984 & 0.49 & 0.34 & 0.42 \\
\hline & H. vinea & YK 660 & AJ 5186 & 0.49 & 0.34 & 0.42 \\
\hline \multirow[t]{2}{*}{2} & $K$. javanica var. javanica & YK 805 & AJ 5195 & 0.60 & - & 0.38 \\
\hline & $K$. javanica var. lafarii & YK 806 & AJ 5197 & 0.60 & - & - \\
\hline \multirow[t]{2}{*}{3} & K. apiculata & YK 800 & IAM 12219 & - & - & 0.36 \\
\hline & H. uvarum & YK 662 & AJ 5184 & - & - & 0.36 \\
\hline \multirow[t]{3}{*}{4} & K. apiculata & YK 801 & AJ 4806 & 0.55 & - & 0.36 \\
\hline & $K$. japonica & YK 802 & IAM 12220 & - & - & 0.36 \\
\hline & H. valbyensis & YK 663 & IFO 1414 & 0.55 & - & 0.36 \\
\hline
\end{tabular}

\begin{tabular}{lllllll}
\hline 5. valbyensis & YK 661 & IAM 4972 & 0.58 & - & 0.35
\end{tabular}

\begin{tabular}{llllll}
\hline 6 & K. corticis & YK 804 & IFO 0631 & 0.49 & - \\
\end{tabular}

Kloeckera and Hanseniaspora are shown in Table 3. These yeasts fell into six groups on the basis of their enzymatic patterns. Kloeckera africana YK 803 and Hanseniaspora vinea YK 660 were included in group 1, and they exhibited identical patterns for all enzymes. Kloeckera javanica var. javanica YK 805 and $K$. javanica var. lafarii YK 806 were included in group 2, and the patterns for FA, 
Hanseniaspora on the basis of the enzymatic patterns.

\begin{tabular}{|c|c|c|c|c|c|c|c|}
\hline $\mathrm{LDH}$ & HK & PGm & G6PDH & Fumarase & GDH & Esterase & $\begin{array}{c}\mathrm{G}+\mathrm{C} \text { contents } \\
\text { of DNAs }(\mathrm{mol} \%)^{a}\end{array}$ \\
\hline 0.15 & 0.43 & 0.49 & 0.28 & 0.24 & 0.14 & 0.60 & 38.0 \\
\hline 0.53 & 0.60 & 0.53 & 0.30 & & & & \\
\hline 0.15 & 0.43 & 0.53 & 0.30 & 0.24 & 0.14 & 0.60 & 37.8 \\
\hline 0.53 & 0.60 & 0.55 & & & & & \\
\hline \multirow[t]{3}{*}{0.46} & 0.45 & 0.58 & 0.29 & 0.27 & 0.16 & 0.52 & 34.6 \\
\hline & & & 0.31 & & & 0.59 & \\
\hline & & & 0.33 & & & & \\
\hline \multirow[t]{3}{*}{0.44} & 0.45 & 0.52 & 0.31 & 0.27 & 0.16 & 0.52 & 33.9 \\
\hline & 0.58 & & 0.33 & & & & \\
\hline & 0.60 & & & & & & \\
\hline \multirow[t]{2}{*}{0.46} & 0.58 & 0.56 & - & 0.29 & - & - & 31.7 \\
\hline & 0.61 & & & 0.35 & & & \\
\hline \multirow[t]{2}{*}{0.46} & 0.58 & 0.44 & - & 0.29 & - & - & 31.5 \\
\hline & 0.61 & 0.54 & & 0.35 & & & \\
\hline \multirow[t]{5}{*}{0.47} & 0.51 & 0.50 & 0.32 & 0.20 & - & 0.62 & 27.1 \\
\hline & 0.55 & & 0.34 & 0.25 & & & \\
\hline & & & 0.36 & & & & \\
\hline & & & 0.40 & & & & \\
\hline & & & 0.41 & & & & \\
\hline \multirow[t]{5}{*}{0.46} & 0.51 & 0.50 & 0.33 & 0.20 & - & 0.62 & 27.1 \\
\hline & 0.55 & & 0.35 & 0.25 & & & \\
\hline & & & 0.38 & & & & \\
\hline & & & 0.40 & & & & \\
\hline & & & 0.41 & & & & \\
\hline \multirow[t]{5}{*}{0.46} & 0.51 & 0.51 & 0.33 & 0.20 & - & 0.70 & 27.6 \\
\hline & 0.55 & 0.53 & 0.35 & 0.25 & & & \\
\hline & & & 0.38 & & & & \\
\hline & & & 0.40 & & & & \\
\hline & & & 0.41 & & & & \\
\hline \multirow[t]{4}{*}{0.50} & 0.49 & 0.48 & 0.45 & 0.24 & & & \\
\hline & 0.55 & 0.53 & 0.47 & 0.29 & - & 0.36 & 31.2 \\
\hline & 0.61 & & & & & 0.52 & \\
\hline & 0.63 & & & & & & \\
\hline 0.19 & 0.40 & - & 0.32 & 0.27 & 0.12 & - & 37.8 \\
\hline \multirow[t]{2}{*}{0.43} & 0.58 & & 0.33 & & & & \\
\hline & & & 0.34 & & & & \\
\hline
\end{tabular}

LDH, HK, G6PDH, fumarase, GDH, and esterase were similar, but not for PGm. The activity of 6PGDH was not detected in either variety. Kloeckera apiculata YK 800 and Hanseniaspora uvarum YK 662 were included in group 3, and they produced identical patterns for $\mathrm{MDH}, \mathrm{LDH}, \mathrm{HK}$, and fumarase, but there was a slight variation for PGm. However, the activities of FA, 6PGDH, GDH, 
G6PDH, and esterase were not detected. Kloeckera apiculata YK 801, Kloeckera japonica YK 802, and Hanseniaspora valbyensis YK 663 were included in group 4, and they had similar patterns for FA, MDH, LDH, HK, G6PDH, and fumarase. However, the activities of 6PGDH and GDH were not detected in any of them. Hanseniaspora valbyensis YK 661 was accommodated in group 5 and Kloeckera corticis YK 804 in group 6.

\section{DISCUSSION}

In the previous paper $(I)$, we reported that possible haploid mating partners can be detected by comparing the enzymatic patterns of various strains in the genera Rhodotorula and Rhodosporidium and that such strains did indeed cross with the known haploid mating-type strains. From these results, it was considered that the technique of polyacrylamide slab gel electrophoresis with specific staining for various enzymes is a useful tool for clarifying the relationship between anamorphic and teleomorphic strains.

Relationship between nine Candida species and their supposed ascosporogenous states on the basis of their enzymatic patterns

The genus Candida is considered to be a heterogeneous collection of ascosporogenous yeast species, and consists of anamorphic strains of basidiomycetous and ascomycetous yeasts (2). NAKASE and Komagata (7) reported that Candida species without urease activity possessed deoxyribonucleic acids (DNAs) with guanine-plus-cytosine $(\mathrm{G}+\mathrm{C})$ contents from 30.0 to $56.6 \mathrm{~mol} \%$, and could be regarded as anamorphs of acsomycetous yeasts. However, the teleomorphs of most of the Candida species have not yet been described.

Mating strains of Candida guilliermondii are now classified in the heterothallic species Pichia guilliermondii. At present, $C$. guilliermondii contains the strains which for some reason are incapable mating (2). C. guilliermondii produced the same enzymatic patterns as $P$. guilliermondii, and this result agreed with those of studies of other biochemical properties $(3,9,11)$. Therefore, C. guilliermondii is considered to be the anamorph of $P$. guilliermondii.

NAKASE (8) reported that 21 strains of Candida krusei could not be distinguished from Pichia kudriavzevii on the basis of their physiological properties and the $\mathrm{G}+\mathrm{C}$ contents of their DNAs. Recently, P. kudriavzevii was assigned to the genus Issatchenkia as I. orientalis, and C. krusei was shown to be the anamorph of $I$. orientalis by DNA-DNA hybridization experiments (17). Three strains in this study, C. krusei YK 501, C. valida YK 507, and I. orientalis ( $P$. kudriavzevii) YK 652, produced identical patterns for their enzymes. Two of the $C$. valida strains tested were once named Candida mycoderma, their DNAs having different $\mathrm{G}+\mathrm{C}$ contents (38.5 and $43.2 \mathrm{~mol} \%$ ) (7). C. valida has been regarded as the anamorph of Pichia membranaefaciens because both species show the same morphological and physiological properties (2). However, of 
two $C$. valida strains, YK 507 is similar to I. orientalis YK 652 and has an identical $\mathrm{G}+\mathrm{C}$ content $(38.5 \mathrm{~mol} \%)$, both strains differing from $P$. membranaefaciens in their $\mathrm{G}+\mathrm{C}$ contents $(3,7)$. Therefore, $C$. valida $\mathrm{YK} 507$ should be regarded as an anamorph of $I$. orientalis. On the other hand, C. valida YK 508 has the same $\mathrm{G}+\mathrm{C}$ content $(43.2 \mathrm{~mol} \%)$ as $P$. membranaefaciens, but it was not similar to $P$. membranaefaciens as regards as the enzymatic patterns. From these results, further studies are required for clarification of the anamorph of $P$. membranaefaciens.

Close relationships were seen between two pairs of anamorph and teleomorph counterparts, Candida macedoniensis and Kluyveromyces marxianus, and Candida pseudotropicalis and Kluyveromyces fragilis, on the basis of their enzymatic patterns. These four species exhibited identical $\mathrm{G}+\mathrm{C}$ contents $(7,21)$ and antigenic structures (9). Physiologically, K. marxianus occupies an intermediate position between Kluyveromyces wickerhamii and $K$. fragilis, and differs from $K$. fragilis chiefly in the fact that lactose is not or only seldom weakly and latently fermented (2). BAK and STENDERUP (13) indicated the existence of a close relationship between $C$. pseudotropicalis and $K$. fragilis, relative DNA-DNA homology $92 \%$, and MARTINI and PhAFF (22) showed $92 \%$ of DNA-DNA homology between $K$. fragilis and $K$. marxianus. Moreover, VAN DER WALT and JoHANnSEN (23) proposed to join ten species, including $K$. marxianus and $K$. fragilis, as a single species after mating studies with auxotrophic mutants. LACHANCE and PHAFF (24) pointed out that the molecular weights of the exo-j-glucanase and immunological distance of $K$. fragilis are the same as those of $K$. marxianus. From these studies and their enzymatic patterns, $K$. fragilis and $K$. marxianus should be combined, and their anamorph should be called $C$. macedoniensis because the description of $C$. macedoniensis antedates that of $C$. pseudotropicalis.

BAK and STENDERUP (13) reported that Candida melinii and Hansenula wingei show $97 \%$ of relative DNA-DNA homology. The similarity in the enzymatic patterns of these species agreed with this.

Candida utilis has the same morphological and physiological properties as Hansenula jadinii, but they apparently differ in sexuality and pathogenicity, $H$. jadinii having the slight ability to produce both ascospores and disease in mammals (2). However, 93-98\% of DNA sequence similarities between C. utilis and $H$. jadinii has been shown by MANACHINI (14). Furthermore, KuRTZMAN et al. (15) reported that these two species share $85 \pm 6.1 \%$ DNA sequence similarity. Thus, the similarity of the enzymatic patterns agreed with the results of DNADNA homology.

Lodderomyces elongisporus was indicated by VAN DER WALT (12) as the teleomorph of Candida parapsilosis because $L$. elongisporus agreed closely with $C$. parapsilosis both morphologically and physiologically. However, MEYER and PHAFF (25) indicated that these yeasts were not closely related by DNA-DNA hybridization. Following this, NAKASE et al. (16) performed a comparative 
taxonomic study on 22 strains of $C$. parapsilosis and one strain of L. elongisporus from the viewpoints of physiological properties, serological characteristics, proton-magnetic-resonance spectra of cell-wall mannans, and $\mathrm{G}+\mathrm{C}$ contents of DNAs, and found that $C$. parapsilosis strains could be assigned to one of two forms. Form II differed from form I in the assimilation of L-arabinose, requirement of thiamine, lack of antigen 24, proton-magnetic-resonance spectra of cell-wall mannans, and lack of excretion of excess riboflavin into synthetic media; these properties are shared with $L$. elongisporus. From these results, NAKASE et al. (16) regarded the strains of $C$. parapsilosis form II as the anamorph of $L$. elongisporus. On electrophoretic comparison of enzymes, $C$. parapsilosis strains were split into two groups. Two strains, YK 509 and YK 510 (group 1), corresponded to form I, and two strains, YK 511 and YK 512 (group 2), to form II. Thus, the opinion of NAKASE et al. (16) was confirmed by the electrophoretic comparison of enzymes. Meyer and Phaff (25) employed strains of $C$. parapsilosis belonging to form I and the type strain of L. elongisporus (YK 690 was derived from the type strain) in DNA-DNA hybridization experiments. Therefore, it is natural that the DNAs of these two species are not homologous. C. parapsilosis group 2 (YK 511 and YK 512) should be regarded as the anamorph of L. elongisporus on the basis of enzymatic patterns and the study of NAKASE et al. (16). Furthermore, the teleomorph corresponding to C. parapsilosis group 1 (YK 509 and YK 510) might be expected in other ascosporogenous yeasts.

Relationship between five Torulopsis species and their supposed ascosporogenous states on the basis of their enzymatic patterns

The heterogeneity of the genus Torulopsis was clearly shown by the serological investigation made by TsuchiYa et al. (9), $\mathrm{G}+\mathrm{C}$ contents of DNAs by NAKASE and Komagata (6), and coenzyme Q system by Yamada and Kondo (11). A number of Torulopsis species are considered to be haploid mating types of ascosporogenous yeast species. However, the clarification of the relatedness between Torulopsis species and ascosporogenous yeasts has hardly been started yet.

Torulopsis holmii is morphologically and physiologically similar to Saccharomyces exiguus, and is regarded as its anamorph (2). The above two species produced identical enzymatic patterns, and result of their enzymatic comparison agreed with those of investigations of antigenic structures (9), $\mathbf{G}+\mathbf{C}$ contents of DNAs (6), and coenzyme Q system (11). Therefore, T. holmii is regarded as the anamorph of $S$. exiguus.

Saccharomyces fermentati, S. rosei, and Torulopsis colliculosa are currently considered synonyms of Torulaspora delbrueckii (18). Torulaspora delbrueckii YK 611 and YK 612 were once named Saccharomyces fermentati and S. rosei, respectively. Three strains of Torulaspora delbrueckii, Torulopsis colliculosa YK 561, and Torulopsis stellata YK 563 possessing Q-6 ${ }^{2}$ show similar enzymatic

\footnotetext{
2 The abbreviation used for coenzyme $\mathrm{Q}$ or ubiquinone is Q- $n$, with $n$ denoting the number of isoprene units in the side-chain.
} 
patterns. Moreover, the results of the enzymatic comparison made by the above workers agreed with those of investigations of $\mathrm{G}+\mathrm{C}$ contents of DNAs $(4,6)$ and the coenzyme Q system (11). From these results, S. fermentati and S. rosei are synonyms of Torulaspora delbrueckii, and Torulopsis colliculosa and T. stellata possessing Q-6 are regarded as anamorphs of $T$. delbrueckii. Furthermore, the teleomorph corresponding to $T$. stellata possessing Q-8 might be expected in other ascosporogenous yeasts.

Torulopsis molischiana is regarded as the anamorph of the homothallic species Hansenula capsulata (2). T. molischiana YK 560 has been isolated and described as a methanol-assimilating yeast by LeE and Komagata (26). H. capsulata also assimilates methanol as a sole carbon source. Moreover, T. molischiana and $H$. capsulata had identical $\mathrm{G}+\mathrm{C}$ contents of DNAs and coenzyme Q system (26). LeE and Komagata (26) examined the electrophoretic pattern of methanol oxidase in one strain each of these two species and reported that the strains exhibited identical patterns. However, in this study on the patterns of the enzymes of glucose metabolism, the two strains were not identical. Therefore, it is not clear whether $T$. molischiana is the anamorph of $H$. capsulata. Further investigations are required for clarification on the relationship between these two species.

Torulopsis candida is a versatile, variable, widely distributed species, and may be regarded as the anamorph of both Debaryomyces hansenii and D. marama (2). T. candida and D. hansenii are exclusive species of the florae in cheese (27). NAKASE and Komagata (4) stated that $T$. candida strains form two groups according to the $\mathrm{G}+\mathrm{C}$ contents of their DNAs (about 36 and $42 \mathrm{~mol} \%$ ), and that the DNAs of D. hansenii and D. marama had $\mathrm{G}+\mathrm{C}$ contents of 36.6 to $37.3 \mathrm{~mol} \%$. Therefore, the strains of $T$. candida with a $\mathrm{G}+\mathrm{C}$ content of about $36 \mathrm{~mol} \% \mathrm{might}$ be anamorphs of $D$. hansenii and $D$. marama. In this study, the eight $T$. candida strains tested formed three groups. All the strains belonging to the first group (YK 551 to YK 555) were once named $T$. famata, and those of the second group (YK 556 and YK 557) were previously named $T$. candida. LODDER and KrEGER-VAN RIJ (28) distinguished T. candida from $T$. famata mainly on the basis of lactose assimilation. However, lactose assimilation ranged from nearly negative, over weakly positive to clearly positive, and these differences in lactose assimilation did not correlate with other differences in morphological or physiological properties (2). For this reason, $T$. candida and T. famata were combined in one species (2). The enzymatic comparison supports the opinion of LODDER and KREGER-VAN RIJ (28). Further studies from other viewpoints are required to determine whether $T$. famata should be included in $T$. candida. The strain YK 558 belonging to the third group was isolated from frozen foods by Komagata and NAKase (29). This strain differed from the members of the first and the second groups of $T$. candida in the enzymatic comparison and $\mathrm{G}+\mathrm{C}$ content of its DNA (4). Therefore, the strain YK 558 should be separated from T. candida. The enzymatic patterns of D. hansenii YK 657 and D. marama YK 
658 do not resemble those of these groups of $T$. candida. From these results, the teleomorph of $T$. candida should be sought in strains of $D$. hansenii and $D$. marama other than YK 657 and YK 658 or in other species.

Relation between the genera Kloeckera and Hanseniaspora on the basis of their enzymatic patterns

The genus Hanseniaspora and its anamorph counterpart Kloeckera are the most frequently encountered genera of apiculate yeasts in various natural products, and have been studied systematically by several workers (30-36).

Miller and PhAFF (30) stated that the species of the genus Hanseniaspora and its anamorph counterpart Kloeckera made a natural group, and that these yeasts comprised four groups. TsUCHIYA et al. (31) recognized three groups in Hanseniaspora-Kloeckera on the basis of antigenic structures; and NAKASE and Komagata (32) reported that the $\mathrm{G}+\mathrm{C}$ content of DNAs from HanseniasporaKloeckera were distributed between 26.8 and $38.0 \mathrm{~mol} \%$, and classified these species into four groups by the $\mathrm{G}+\mathrm{C}$ content of their DNAs and physiological properties. Furthermore, only the coenzyme Q-6 system was observed in the two genera by Yamada et al. (34). Since then MeYER et al. (36) have revealed the existence of six distinct species in the genus Hanseniaspora, namely, Hanseniaspora valbyensis, $H$. uvarum, $H$. guilliermondii, $H$. occidentalis, $H$. osmophila, and $H$. vinea with their anamorphic states Kloeckera japonica, K. apiculata, K. apis, $K$. javanica, $K$. corticis, and $K$. africana, respectively, on the basis of DNA base composition and DNA-DNA reassociation. The relationships of Hanseniaspora and Kloeckera species proposed by the various authors $(30-33,35,36)$ are presented in Table 4. The grouping of Hanseniaspora and Kloeckera by their en-

Table 4. The relationships of Hanseniaspora to

\begin{tabular}{|c|c|c|c|c|}
\hline Group & Anamorph & $\begin{array}{l}\text { Miller and } \\
\text { PhafF }(30)\end{array}$ & TsuchIYA et al. (31) & $\begin{array}{l}\text { NAKASE and } \\
\text { KomAGATA (32) }\end{array}$ \\
\hline 1 & $K$. africana & $?$ & $\begin{array}{l}\text { H. osmophila } \\
\text { H. vinea }\end{array}$ & $\begin{array}{l}\text { H. osmophila } \\
\text { H. vinea }\end{array}$ \\
\hline 2 & $K$. javanica & $?$ & $?$ & $?$ \\
\hline 3 & K. apiculata & $\begin{array}{l}\text { H. uvarum } \\
\text { H. valbyensis }\end{array}$ & $\begin{array}{l}\text { H. guilliermondii } \\
\text { H. valbyensis } \\
\text { H. uvarum }\end{array}$ & $\begin{array}{l}\text { H. guilliermondii } \\
\text { H. valbyensis } \\
\text { H. uvarum }\end{array}$ \\
\hline 4 & $K$. japonica & $\begin{array}{l}\text { H. uvarum } \\
\text { H. valbyensis }\end{array}$ & $\begin{array}{l}\text { H. guilliermondii } \\
\text { H. valbyensis } \\
\text { H. uvarum }\end{array}$ & H. valbyensis \\
\hline 5 & K. apis & $?$ & $?$ & $?$ \\
\hline 6 & K. corticis & H. osmophila & $\begin{array}{l}\text { H. osmophila } \\
\text { H. vinea }\end{array}$ & $\begin{array}{l}H . \text { osmophila } \\
H . \text { vinea }\end{array}$ \\
\hline
\end{tabular}

?, unknown; -, not tested. 
zymatic patterns coincided with the grouping made by MEYER et al. (36) by DNADNA reassociation.

The members of group 1 consisted of $K$. africana and $H$. vinea from their enzymatic patterns. NAKASE and Komagata (32) included $K$. corticis in this group because of the $\mathrm{G}+\mathrm{C}$ content of its DNA. However, $K$. corticis was not similar to $H$. vinea and $K$. africana for the respective enzymes and was, therefore, accommodated in group 6. MiLler and PhAFF (30) pointed out that K. corticis differed from $K$. africana because the former could not assimilate sucrose. TsuCHIYA et al. (31) included $K$. africana in the group of $K$. corticis on the basis of antigenic structures. Moreover, NAKASE and Komagata (32) stated that the separation of $K$. africana from $K$. corticis by assimilation of sucrose was not a reasonable proposition because sucrose assimilation was variable. In the DNA reassociation study made by MEYER et al. (36), K. africana and $K$. corticis exhibited a relative homology of $45-56 \%$. Therefore, K. corticis was regarded as the anamorph of $H$. osmophila (36). In this study, the results of MiLler and PhAFF (30) and Meyer et al. (36) were supported.

In group 2, each strain of two varieties of $K$. javanica exhibited identical enzymatic patterns, and they could not be separated from each other. MiLLER and Phaff (30) separated $K$. lafarii as $K$. javanica var. lafarii from $K$. javanica var. javanica on the basis of the lack of assimilation and fermentation of raffinose. However, NAKASE and KOMAGATA (32) intimated that assimilation and fermentation of raffinose by the $K$. javanica group were always latent, or latent and weak, and that these properties have minor taxonomic value in the classification of Hanseniaspora and Kloeckera, and therefore, there is no need to retain K. javanica var. lafarii. The results of our enzymatic comparison support the opinion of

Kloeckera species as proposed by several workers.

\begin{tabular}{|c|c|c|c|}
\hline SмIтH (33) & SMITH et al. (35) & Meyer et al. (36) & $\begin{array}{c}\text { The enzymatic } \\
\text { patterns }\end{array}$ \\
\hline - & - & H. vinea & H. vinea \\
\hline H. occidentalis & - & H. occidentalis & - \\
\hline - & H. uvarum & H. uvarum & H. uvarum \\
\hline - & - & H. valbyensis & H. valbyensis \\
\hline - & H. guilliermondii & H. guilliermondii & - \\
\hline - & - & H. osmophila & - \\
\hline
\end{tabular}


NAKase and Komagata (32). Therefore, $K$. javanica var. lafarii should be regarded as the synonym of $K$. javanica. TsuchIYA et al. (3I) deduced from the antigenic structures that the $K$. javanica group was a hybrid of the $K$. africana and $K$. apiculata groups. This assumption was supported by SPENCER and GORIN (37) on the basis of proton-magnetic-resonance spectra of mannans isolated from these yeasts. On the other hand, NAKASE and Komagata (32) stated that two microorganisms whose DNA differed in $\mathrm{G}+\mathrm{C}$ content by about $7 \mathrm{~mol} \%$ seem unlikely to be able to hybridize. This assumption of hybridization of the $K$. africana group with the $K$. apiculata group could not be supposed by the electrophoretic comparison of enzymes. Much more evidence is required for the deduction of TsUCHIYA et al. (31). H. occidentalis was regarded as the teleomorph of $K$. javanica by SMITH (33). Moreover, a high degree of DNA-DNA reassociation $(75-100 \%)$ was demonstrated between the two species by MEYER et al. (36). Since the teleomorphs with enzymatic patterns similar to those with their anamorphic Candida states also had homologous DNAs it may be supposed that the above two species will be found to have similar enzymatic patterns.

The members of group 3 consisted of the species $K$. apiculata and $H$. uvarum from their enzymatic patterns. NAKASE and Komagata (32) included $\mathrm{H}$. valbyensis $\mathrm{YK} 661$ (IAM 4972=AJ 4277) in this group from the $\mathrm{G}+\mathrm{C}$ content of the DNAs. However, H. valbyensis YK 661 was not similar to the starins of group 3 for the respective enzymes, therefore, $H$. valbyensis YK 661 was accommodated in group 5. There is a high degree of DNA-DNA reassociation (95$100 \%$ ) between $K$. apiculata and $H$. uvarum but not between $K$. apiculata and $H$. valbyensis $(11-16 \%)(36)$. From these results, $K$. apiculata belonging to group 3 should be regarded as the anamorph of $H$. uvarum.

Three species $K$. apiculata, K. japonica, and $H$. valbyensis produced identical enzymatic patterns and formed group 4. In the monograph of LODDER and Kreger-VAN RiJ (28), K. japonica described by SAIto and OHTANi (38) was treated as a synonym of $K$. apiculata. The strains of $K$. apiculata were split between two groups, group 3 and group 4, on the basis of their enzymatic patterns and $\mathrm{G}+\mathrm{C}$ contents of DNAs. The type strain of $K$. apiculata is in group 3. A high degree of DNA-DNA reassociation $(94-100 \%$ ) between $K$. japonica and $H$. valbyensis was demonstrated by MEYER et al. (36). Therefore, K. apiculata YK 801 belonging to group 4 should be identified as $K$. japonica, and $K$. japonica should be regarded as the anamorph of $H$. valbyensis.

The strains of $H$. valbyensis divided into two groups, group 4 and group 5 . LODDER and KREGER-VAN RIJ (28) indicated $H$. guilliermondii as being a synonym of $H$. valbyensis, while KREgeR-VAN RiJ and AHEARn (39) suggested a separation of $H$. guilliermondii from $H$. valbyensis by the number of ascospores per ascus and growth at $37^{\circ}$. NAKASE and Komagata (32) divided $H$. valbyensis strains between group 3 and group 4 of their system and included $H$. guilliermondii in group 3 on the basis of the $\mathrm{G}+\mathrm{C}$ content of their DNAs. The H. valbyensis 
strain in group 4 is regarded as the teleomorph of $K$. japonica from the enzymatic patterns and DNA-DNA reassociation experiments done (36). The strain YK 661 of $H$. valbyensis should be identified as $H$. guilliermondii. SMITH et al. (35) described $K$. apis as the anamorph of $H$. guilliermondii on the basis of DNA-DNA reassociation studies. $K$. apis was not investigated in this study. However, a high degree of DNA-DNA reassociation (91-100\%) was demonstrated between $K$. apis and $H$. guilliermondii by MEYER et al. (36). Therefore, these species may be expected to have similar patterns when their enzymes are compared electrophoretically.

As shown above, the enzymatic patterns of Candida, Torulopsis, and Kloeckera species coincided with those of their supposed ascosporogenous states. Furthermore, a close relationship between the degree of DNA-DNA homology and electrophoretic similarity of the enzymes can be discerned. We conclude from this that the electrophoretic comparison of enzymes is useful for studying the relationship of an asporogenous yeast species to a sporogenous one and allows the relationship between a teleomorph species and its anamorphic state to be more clearly established.

We thank Prof. S. Goto (Yamanashi University) and Dr. D. Yarrow (Centraalbureau voor Schimmelcultures, Yeast Division, Delft, The Netherlands) for their encouragement and invaluable suggestions. We also thank Dr. T. Iijima (Institute for Fermentation, Osaka), Dr. K. Yamada (Central Research Laboratories, Ajinomoto Co., Inc., Kawasaki), and Dr. C. P. Kurtzman (Northern Regional Research Center, Peoria, U.S.A.) for supplying the cultures.

\section{REFERENCES}

1) M. Yamazaki and K. Komagata, Int. J. Syst. Bacteriol., 31, 361 (1981).

2) J. Lodder (ed.), The Yeasts, a Taxonomic Study, North-Holland Publ. Co., Amsterdam (1970).

3) T. Nakase and K. Komagata, J. Gen. Appl. Microbiol., 16, 551 (1970).

4) T. Nakase and K. Komagata, J. Gen. Appl. Microbiol., 17, 43 (1971).

5) T. Nakase and K. Komagata, J. Gen. Appl. Microbiol., 17, 77 (1971).

6) T. NaKase and K. Komagata, J. Gen. Appl. Microbiol., 17, 161 (1971).

7) T. Nakase and K. Komagata, J. Gen. Appl. Microbiol., 17, 259 (1971).

8) T. Nakase, J. Gen. Appl. Microbiol., 17, 383 (1971).

9) T. Tsuchiya, Y. Fukazawa, and S. Kawakita, Mycopathol. Mycol. Appl., 26, 1 (1965).

10) P. A. Gorin and J. F. T. Spencer, Adv. Appl. Microbiol., 13, 25 (1970).

11) Y. Yamada and K. Kondo, Proc. 2nd Int. Specialized Symp. Yeasts, Tokyo, Japan, 1972, p. 63 (1973).

12) J. P. van Der Walt, Antonie van Leeuwenhoek J. Microbiol. Serol., 32, 1 (1966).

13) A. L. BaK and A. Stenderup, J. Gen. Microbiol., 59, 21 (1969).

14) P. L. Manachini, Antonie van Leeuwenhoek J. Microbiol. Serol., 45, 451 (1979).

15) C. P. Kurtzman, C. J. Johnson, and M. J. Smiley, Mycologia, 71, 844 (1979).

16) T. Nakase, K. Komagata, and Y. Fukazawa, J. Gen. Appl. Microbiol., 25, 375 (1979).

17) C. P. Kurtzman, M. J. Smiley, and C. J. Johnson, Int. J. Syst. Bacteriol., 30, 503 (1980).

18) J. A. Barnett, R. W. Payne, and D. Yarrow, A Guide to Identifying and Classifying Yeasts, Cambridge University Press, London (1979). 
19) D. Yarrow and S. A. Meyer, Int. J. Syst. Bacteriol., 28, 611 (1978).

20) M. J. Siciliano and C. R. Shaw, In Chromatographic and Electrophoretic Techniques, 4th Ed., Vol. 2, ed. by I. Smith, William Heinemann Medical Books Ltd., London, p. 185 (1976).

21) T. Nakase and K. Komagata, J. Gen. Appl. Microbiol., 17, 227 (1971).

22) A. Martini and H. J. Phaff, Ann. Microbiol., 23, 59 (1973).

23) J. P. van der Walt and E. Johannsen, Antonie van Leeuwenhoek J. Microbiol. Serol., 45, 281 (1979).

24) M. A. Lachance and H. J. Phaff, Int. J. Syst. Bacteriol., 29, 70 (1979).

25) S. A. Meyer and H. J. Phaff, Proc. 1st Int. Specialized Symp. Yeasts, Smolenice, 1971, p. 375 (1972).

26) J. D. Lee and K. Komagata, J. Gen. Appl. Microbiol., 26, 133 (1980).

27) T. NaKase and K. Komagata, J. Food Hyg. Soc. Jpn., 18, 346 (1977).

28) J. Lodder and N. J. W. Kreger-van RiJ, The Yeasts, a Taxonomic Study, North Holland Pub. Co., Amsterdam (1952).

29) K. Komagata and T. Nakase, J. Food Hyg. Soc. Japan, 8, 58 (1967).

30) M. W. Miller and H. J. Phaff, Mycopathol. Mycol. Appl., 10, 113 (1958).

31) T. Tsuchiya, S. Kawakita, M. Imai, and K. Minagawa, Jpn. J. Exp. Med., 36, 555 (1966).

32) T. Nakase and K. Komagata, J. Gen. Appl. Microbiol., 16, 241 (1970).

33) M. T. Smith, Antonie van Leeuwenhoek J. Microbiol. Serol., 40, 441 (1974).

34) Y. Yamada, M. Nojiri, M. Matsuyama, and K. Kondo, J. Gen. Appl. Microbiol., 22, 325 (1976).

35) M. T. Smith, F. P. Simone, Jr., and S. A. Meyer, Antonie van Leeuwenhoek J. Microbiol. Serol., 43, 219 (1977).

36) S. A. Meyer, M. T. Smith, and F. P. Simone Jr., Anotnie van Leeuwenhoek J. Microbiol. Serol., 44, 79 (1978).

37) J. F. T. SPencer and P. A. J. Gorin, J. Bacteriol., 96, 180 (1968).

38) K. SAito and Y. Ohtani, Jozogaku Zasshi, 9, 6 (1931).

39) N. J. W. Kreger-van RiJ and D. G. Ahearn, Mycologia, 60, 604 (1968).

40) Y. Yamada, T. Okada, O. Ueshima, and K. Kondo, J. Gen. Appl. Microbiol., 19, 189 (1973).

41) Y. Yamada, M. Arimoto, and K. Kondo, J. Gen. Appl. Microbiol., 22, 293 (1976). 